\title{
Synthesis, characterization, and antibacterial activities of a novel nanohydroxyapatite/zinc oxide complex
}

\author{
Gang Zhou, ${ }^{1,2}$ Yubao Li, ${ }^{1}$ Wei Xiao, ${ }^{3}$ Li Zhang, ${ }^{1}$ Yi Zuo, ${ }^{1}$ Jing Xue, ${ }^{4}$ John A. Jansen ${ }^{5}$ \\ ${ }^{1}$ Research Center for Nano-Biomaterials, Analytical and Testing Center, Sichuan University, Chengdu 610064, China \\ ${ }^{2}$ College of Chemistry, Sichuan University, Chengdu 610064, China \\ ${ }^{3}$ College of Life Science, Sichuan University, Chengdu 610064, China \\ ${ }^{4}$ Key Lab of Oral Biomedical Engineering, Sichuan University, Chengdu 610041, China \\ ${ }^{5}$ Department of Periodontology and Biomaterials, Radboud University Nijmegen Medical Center, Nijimegen, \\ The Netherlands
}

Received 3 November 2006; revised 26 March 2007; accepted 15 May 2007

Published online 26 September 2007 in Wiley InterScience (www.interscience.wiley.com). DOI: 10.1002/jbm.a.31527

\begin{abstract}
Nanohydroxyapatite (n-HA)/zinc oxide $(\mathrm{ZnO})$ complex was synthesized by a direct precipitation method, and the antibacterial capability and antibacterial mechanism of this complex were investigated in this article. Transmission electron microscope (TEM), Fourier transform infrared, X-ray photoelectronic spectroscopy (XPS), and X-ray diffraction (XRD) were used to analyze the materials. In addition, the antibacterial capacity of n$\mathrm{HA} / \mathrm{ZnO}$ complex was examined by bacteriolytic plate, inhibition effect, and antibacterial rate assays under light or without light. Furthermore, agarose gel electrophoresis of plasmid DNA (pUC18) was used to study biocidal action of this complex. The results of TEM observation revealed that the complex's rods had a single crystalline obelisk-like hexagonal wurtzite structure and the crystal retained the nanometer size. XRD analysis indicated that the phase of $\mathrm{ZnO}$ appeared and the lattice parameters of
\end{abstract}

n-HA and $\mathrm{ZnO}$ changed. XPS spectra showed that the bonding energy of $\mathrm{Ca}, \mathrm{P}$, and $\mathrm{O}$ atoms changed in the complex. The analyses also showed that the two phases of $\mathrm{ZnO}$ and n-HA combined closely. Further, the results of the antibacterial test revealed that this complex possessed strong antibacterial capability; the antibacterial rate was $99.45 \%$ to $S$. aureus and $95.65 \%$ to E. coli under light, respectively. The antibacterial activity of this complex under light was better than without light, which was attributed to the generation of $\cdot \mathrm{OH}$ under light. From the agarose gel electrophoresis, the dissolving solution of this complex could catalyze the cleavage of pUC18. (C) 2007 Wiley Periodicals, Inc. J Biomed Mater Res 85A: 929-937, 2008

Key words: nanohydroxyapatite; zinc oxide; antibacterial capability; antibacterial mechanism

\section{INTRODUCTION}

Clinical success of implants depends upon the integration of a biomaterial device into the surrounding body tissues. In addition to the encouragement of the cellular interactions, the biomaterial surface has to discourage adhesion of infectious bacteria, which are a common cause of implant failure. ${ }^{1,2}$ Polymethylmetacrylate (PMMA) loaded with antimicrobial agents is used for treatment and prevention of orthopedic infections. ${ }^{3}$ Unfortunately, PMMA bone cement is associated with several disadvantages, like reducing biocompatibility with bone, short duration of release, and thermal damage to the antibiotics. ${ }^{4}$

Correspondence to: Y. Li; e-mail: nic7504@scu.edu.cn

Contract grant sponsor: Ministry of Science and Technology of China; contract grant number: 2004CB 720604
Therefore, in recent years, the use of inorganic antibacterial biomaterials is highlighted for the control of bacteria. ${ }^{5}$ The advantages of inorganic biomaterials are their safety, durability, and stability, compared with organic antibacterial biomaterials. ${ }^{6}$

Zinc oxide $(\mathrm{ZnO})$ is an inorganic material, which processes unique properties such as nontoxicity and antiseptic effect. ${ }^{7-10} \mathrm{ZnO}$ has already been studied extensively. Song et al. found that $\mathrm{ZnO}$ exhibited antibacterial activity of E. coli. ${ }^{11}$ Another inorganic material that has been used widely as biomaterial is hydoxyapatite (HA) ceramic. This material is known for its good biocompatibility and bioactive bone behavior. ${ }^{12-15}$ Our intention is to prepare a new anti-inflammatory biomaterial that combines the favorable biological characteristics of $\mathrm{HA}$ and possess antimicrobial activity as expressed by $\mathrm{ZnO}$.

In this article, a direct precipitation method was used to prepare a $\mathrm{ZnO}$ bearing n-HA slurry with a 
nanometer-sized crystal size. The properties of this complex were characterized and analyzed, using XPS, IR, TEM, and XRD. Bacteriolytic plate, inhibition effect, and antibacterial rate assays were used to measure the antibacterial activities of materials against $E$. coli and $S$. aureus, and to discuss the antibacterial mechanism.

\section{MATERIALS AND METHODS}

\section{Preparation of the materials}

n-HA slurry was synthesized by a precipitation method. ${ }^{16}$ Zinc nitrate $\left[\mathrm{Zn}\left(\mathrm{NO}_{3}\right)_{2} \cdot 6 \mathrm{H}_{2} \mathrm{O}\right]$, PEG-400, and ammonia (25 wt \%), purchased from Chengdu Chemical Reagent Company, were of analytical grade. Firstly, $\mathrm{Zn}\left(\mathrm{NO}_{3}\right)_{2} \cdot 6 \mathrm{H}_{2} \mathrm{O}$ and PEG-400 powders were dissolved into aqueous solution, and then ammonia was dropped slowly into the solution with vigorous stirring. The dropping speed was near $4 \mathrm{~mL} \mathrm{~min}{ }^{-1}$ and the reaction was carried out in ambient condition. The rotation speed of stirrer was adjusted to $1000 \mathrm{rpm}$. After titration, the precursor of $\mathrm{Zn}(\mathrm{OH})_{2}$ was introduced into n-HA slurry according to the n-HA/ $\mathrm{ZnO}$ weight ratio of 9:1, and then kept stirring for $2 \mathrm{~h}$. Then the obtained slurry was shaken in ultrasonic instrument for $2 \mathrm{~h}$ and aged for another $24 \mathrm{~h}$. Finally, the white precipitate was fully washed with deionized water and ethanol, respectively, and dried at $80^{\circ} \mathrm{C}$. The obtained powder was calcined at $300^{\circ} \mathrm{C}$ for $2 \mathrm{~h}$.

\section{Characterization of materials}

The content of $\mathrm{Zn}$ element in the $\mathrm{n}-\mathrm{HA} / \mathrm{ZnO}$ complex was analyzed by Atom adsorption spectrometer (AAS, VARIAN Spectr AA 220FS).

X-ray photoelectronic spectroscopy (XPS, XSAM 800) was utilized to analyze the surface area of the powder.

Chemical analysis of the complex was carried out by a Fourier transform infrared (FTIR) spectrophotometer (Thermo Nicolet 170SX) in the range from 4000 to $400 \mathrm{~cm}^{-1}$ at $2 \mathrm{~cm}^{-1}$ resolution averaging 100 scans.

The microstructure of the $\mathrm{n}-\mathrm{HA} / \mathrm{ZnO}$ complex was observed with a transmission electron microscope (TEM, JME-100CX).

$X R D$ was used to determine the structure of the material. XRD analysis was performed with a DX-1000 analyzer $(\mathrm{Cu}-\mathrm{K} \alpha)$. The samples were measured in the $2 \theta$ range from $10^{\circ}$ to $70^{\circ}$ (scan speed of $0.02^{\circ}$ per second).

\section{Antibacterial test}

All antibacterial tests were performed with bacteria JM no. 109 Escherichia coli (E. coli), ATCC no. 26003 Staphylococcus aureus (S. aureus), supplied by Microbial Laboratory of College of Life Science, Sichuan University, China.

\section{Bacteriolytic plate assay}

First, an inoculum with this strain was grown overnight in $2 \mathrm{~mL} \mathrm{NB}$ media $(10 \mathrm{~g} / \mathrm{L}$ Peptone, $5 \mathrm{~g} / \mathrm{L} \mathrm{NaCl}, 3 \mathrm{~g} / \mathrm{L}$ Beef extract) at $37^{\circ} \mathrm{C}$ with shaking. Then, a soft agar-incubation mixture was made containing $15 \mathrm{~mL}$ of $0.8 \%$ agar previously melted at $45^{\circ} \mathrm{C}$ with $50 \mu \mathrm{L}$ of the bacterial cell inoculums. The $\mathrm{n}-\mathrm{HA}$ and $\mathrm{n}-\mathrm{HA} / \mathrm{ZnO}$ powder was put into the shape of a disc $\left(\phi 12.5 \times 2 \mathrm{~mm}^{2}\right)$ under UV light and without light irritation, then putting them on the softagar layer. Finally, the plates were incubated at $37^{\circ} \mathrm{C}$ for $24 \mathrm{~h}$ under light and without light, respectively. After incubation, the inhibition zones were visually inspected along the edge of "discs" and the plates were photographed. In this assay, all the data were the means of three parallel experiments $(d=3)$.

\section{Inhibition effects assay}

To determine the antibacterial activity, $0.1 \mathrm{~mL}$ diluted bacterial suspension was cultured in $5 \mathrm{~mL}$ liquid NB medium containing n-HA/ZnO complex for different periods. The inoculated medium was maintained at $37^{\circ} \mathrm{C}$ with shaking. The number of bacteria was counted by ultra-violet absorption of the cultured medium at $260 \mathrm{~nm}\left(A_{260}\right)$. All the data were the means of three parallel experiments $(d=3)$ of which the discrepancies were less than $5 \%$.

\section{Antibacterial rate assay}

The antibacterial rate was calculated by the method of counting lawn. ${ }^{17}$ Hundred microliters of an overnight culture of E. coli and S. aureus was diluted into $10 \mathrm{~mL}$ NB liquid cultures, respectively. Then the liquid is transferred to the sterile tube containing $1 \mathrm{~g}$ of specimen's powder. The tubes were incubated $24 \mathrm{~h}$ at $37^{\circ} \mathrm{C}$ and the bacterial growth was measured by optical density at $260 \mathrm{~nm}$.

\section{Interaction between dissolving solution of n-HA/ $\mathrm{ZnO}$ complex and plasmid DNA}

Plasma DNA (pUC18) was distracted from E. coli (JM no. 109) by alkaline lyses method. ${ }^{18}$ Ten microliters of diluted pUC18 suspension was cultured in EP. Then, $10 \mu \mathrm{L}$ of the dissolved $\mathrm{n}-\mathrm{HA} / \mathrm{ZnO}$ complex was transferred into $\mathrm{EP}$ and incubated at $37^{\circ} \mathrm{C}$ without light. After 1, 5, 10, 15, 30,60 , and $300 \mathrm{~min}$ of incubation, $3 \mu \mathrm{L}$ suspension was extracted and assayed by agarose gel electrophoresis.

\section{RESULTS AND DISCUSSION}

\section{XPS analysis}

Figure 1 shows the XPS spectra of n-HA and n$\mathrm{HA} / \mathrm{ZnO}$ complex. Figure 2 shows the XPS spectrum of $\mathrm{Zn} 2 \mathrm{P}$ in n-HA/ZnO complex. From Figures 


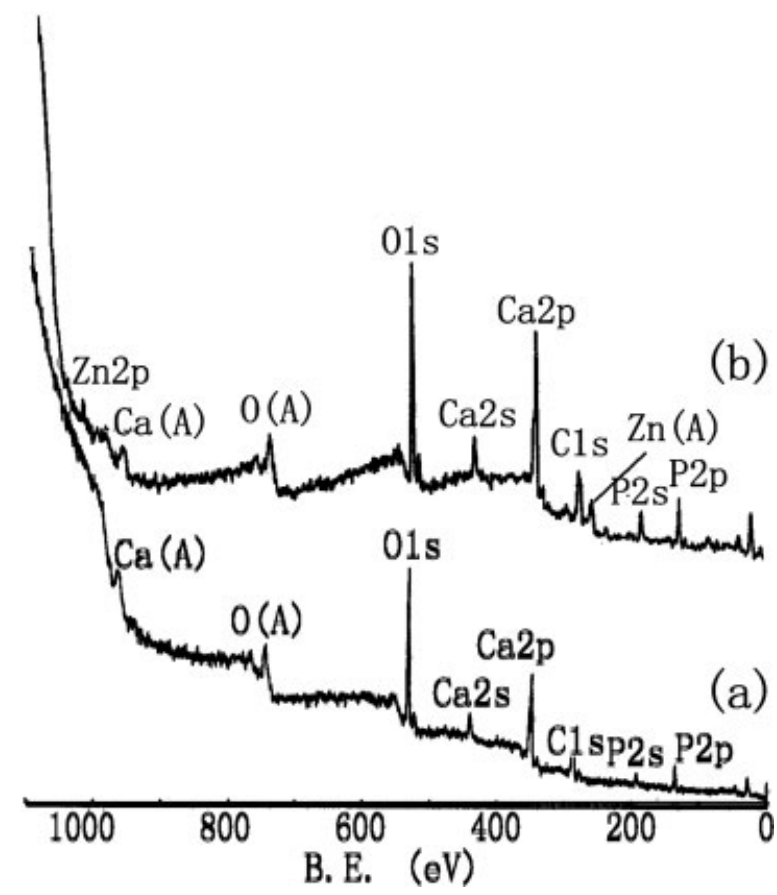

Figure 1. XPS spectra of n-HA (a) and n-HA/ $\mathrm{ZnO}$ complex (b) powder calcined at $300^{\circ} \mathrm{C}$.

1(b) and 2, it can be deduced that the binding energy peak of $\mathrm{Zn}$ is at $1022.2 \mathrm{eV}$, which belongs to $\mathrm{ZnO}$ according to Hoogewijs et al., ${ }^{19}$ and Gaarenstroom and Winograd. ${ }^{20}$ Besides, the binding energy of $\mathrm{Ca}$, $\mathrm{P}$, and $\mathrm{O}$ atoms has some differences between n-HA (Ca: $345.5 \mathrm{eV}$; O: $530.2 \mathrm{eV}$; P: $132.5 \mathrm{eV}$ ) and the complex (Ca: $347.2 \mathrm{eV}$; O: $531.2 \mathrm{eV}$; P: $133.3 \mathrm{eV}$ ). The values of elements in the complex are higher than those of n-HA, which implies that some interaction or chemical bonding may be formed between the two phases, such as between $\mathrm{Ca}^{2+}, \mathrm{OH}^{-}, \mathrm{PO}_{4}^{3-}$, and $\mathrm{Zn}^{2+}$ in $\mathrm{n}-\mathrm{HA} / \mathrm{ZnO}$ complex.

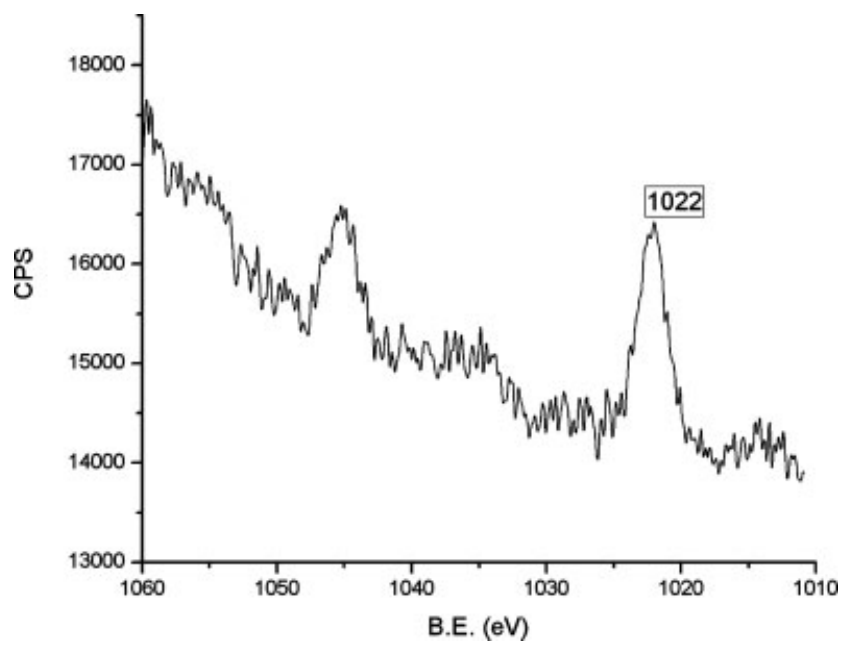

Figure 2. XPS spectrum of $\mathrm{Zn} 2 \mathrm{P}$ in the $\mathrm{n}-\mathrm{HA} / \mathrm{ZnO}$ complex calcined at $300^{\circ} \mathrm{C}$.

\section{IR analysis}

IR spectra of n-HA and n-HA/ ZnO complex powder are shown in Figure $3(a, b)$. It can be seen that the major bands of $\mathrm{HA}$ associated with $\mathrm{PO}_{4}^{3-}$ (1094, 1036, 963, 604, and $566 \mathrm{~cm}^{-1}$ ) and $\mathrm{OH}^{-}$(3568 and $628 \mathrm{~cm}^{-1}$ ) appear in Figure 3(b). The bands attributed to $\mathrm{CO}_{3}^{2-}\left(1350-1450 \mathrm{~cm}^{-1}\right)$ and $\mathrm{HPO}_{4}^{-}(873$ $\mathrm{cm}^{-1}$ ) also appeared in the spectra in Figure 3(a,b). Kumar et al. ${ }^{21}$ report that B-type $\left(\mathrm{CO}_{3}^{2-}\right.$ for $\left.\mathrm{PO}_{4}^{3-}\right)$ substituted $\mathrm{HA}$ is present. IR spectra also show that there are some changes in the frequencies of $\mathrm{PO}_{4}^{3-}$ and $\mathrm{OH}^{-}$, shifting to the low wave numbers in the complex, which is in agreement with XPS analysis. Meanwhile, this movement indicates that the positive end of the $\mathrm{OH}^{-}$dipole approaches the negative Ca vacancies $(\mathrm{Vca}){ }^{22}$ which contributes to the wave numbers shift. Besides, the sorption of $\mathrm{Zn}$ from $\mathrm{ZnO}$ is probably favored by suitable $\mathrm{O}-\mathrm{O}$ separation between $\mathrm{PO}_{4}^{3-}$ groups of $\mathrm{HA}^{23}$ which is the bidentate coordination of $\mathrm{Zn}$ with $\mathrm{PO}_{4}^{3-}$ tetrahedral, as shown in Figure 4.

\section{TEM observation}

As shown in Figure 5, TEM micrograph illustrates that the n-HA/ZnO complex possesses a uniform and ultra fine microstructure with an average grain size of $80-90 \mathrm{~nm}$ in length and $15-30 \mathrm{~nm}$ in diameter, with no glassy or amorphous interface along the grain boundaries. Also, the $\mathrm{ZnO}$ grains combined

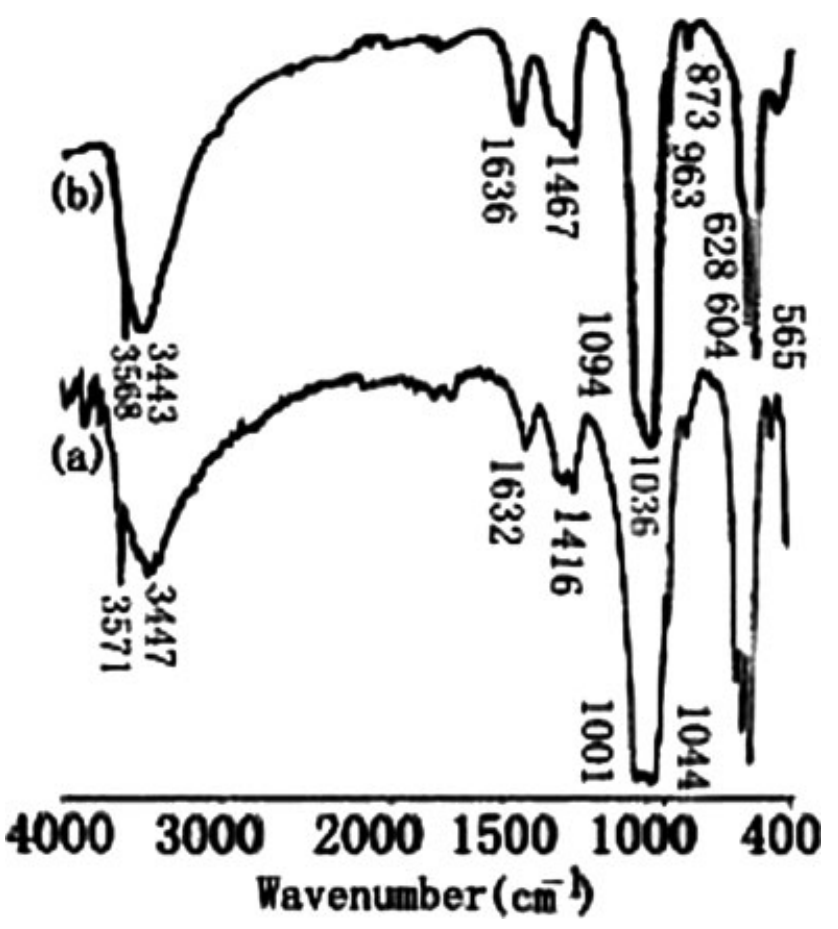

Figure 3. IR spectra of $\mathrm{n}-\mathrm{HA}$ (a) and $\mathrm{n}-\mathrm{HA} / \mathrm{ZnO}$ complex (b) powder calcined at $300^{\circ} \mathrm{C}$. 


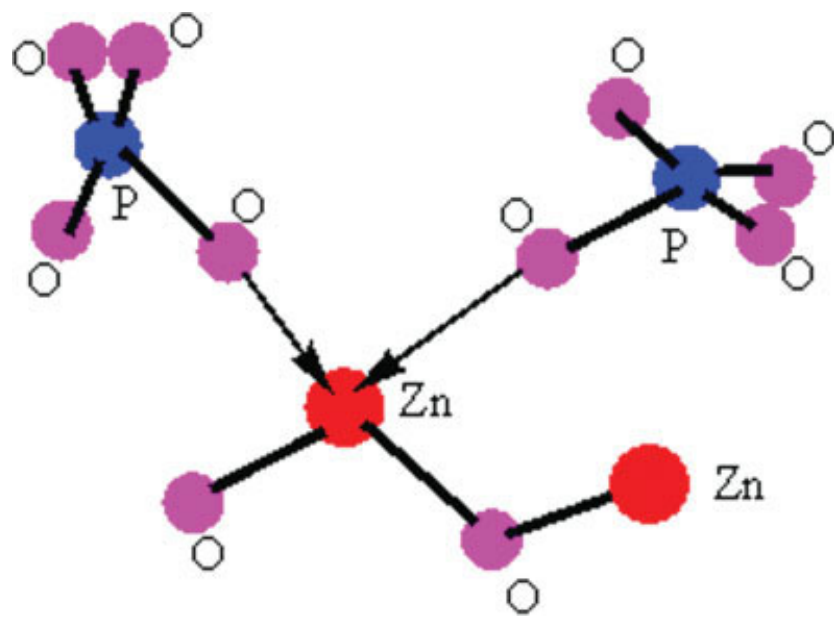

Figure 4. Schematic model illustrating possible coordination bonding. [Color figure can be viewed in the online issue, which is available at www.interscience.wiley.com.]

with n-HA crystals without phase-separation. It can also be seen that the complex is composed of welldefined crystals with an obelisk-like hexagonal wurtzite structure.

\section{XRD analysis}

According to XRD data calculated by Jade 6 software, the mean size of $\mathrm{n}-\mathrm{HA}$ is about $58.66 \pm 0.4$ $\mathrm{nm}$, and $\mathrm{ZnO}$ crystal is about $28.36 \pm 0.6 \mathrm{~nm}$, which is in agreement with the TEM observations. This indicates also that the complex is a nanosized material.

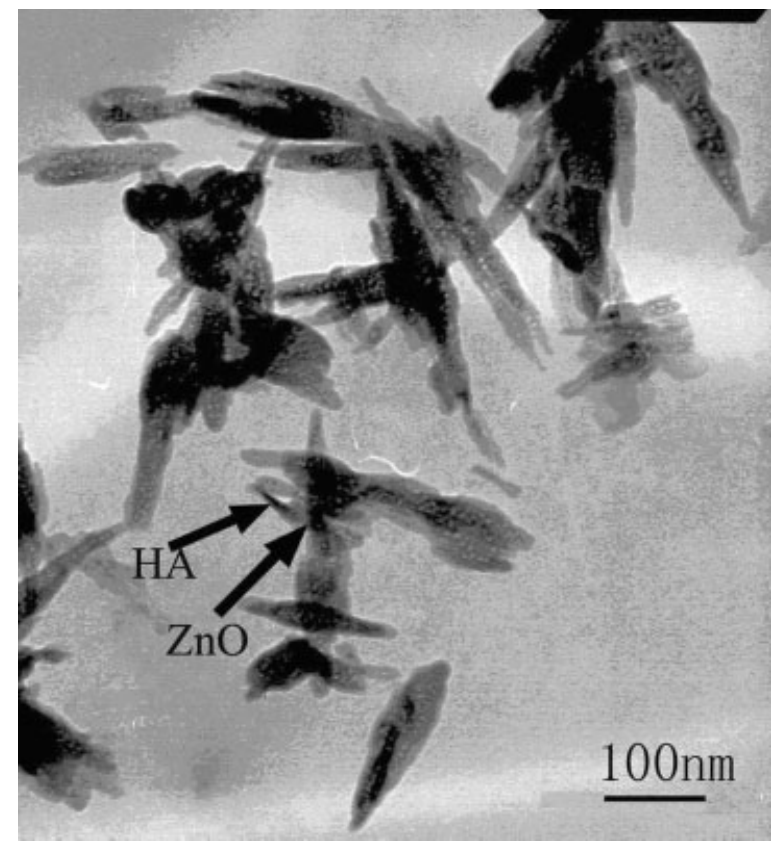

Figure 5. TEM photo of n-HA/ZnO complex.

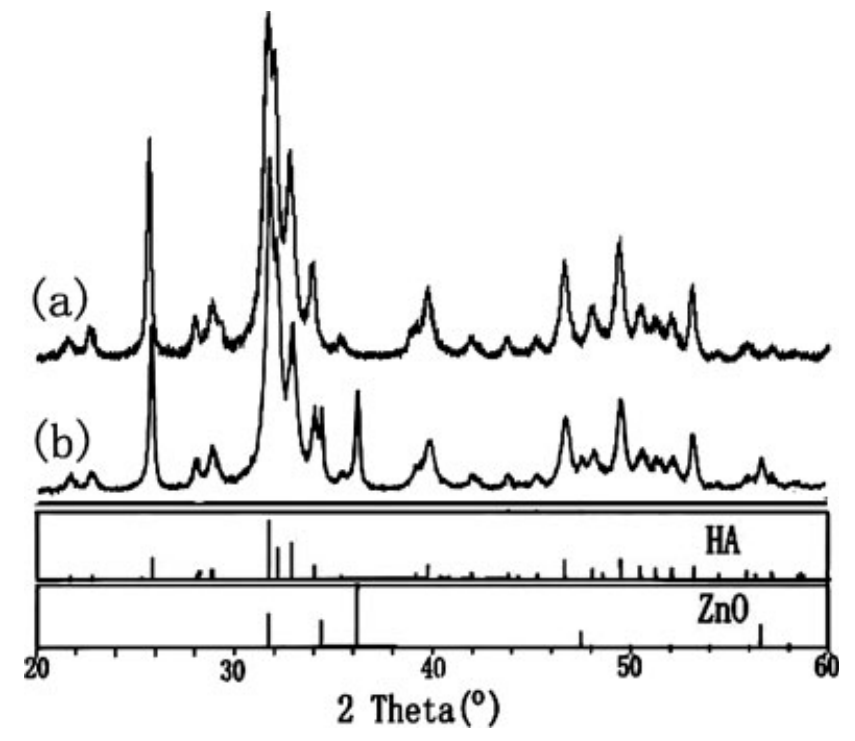

Figure 6. XRD patterns of n-HA (a) and n-HA/ ZnO complex (b) powder calcined at $300^{\circ} \mathrm{C}$.

Figure 6 shows the appearance of the characteristic $\mathrm{ZnO}$ peaks at $34.13^{\circ}, 38.48^{\circ}, 47.68^{\circ}$, and $56.70^{\circ}$ corresponding to the (100), (002), (102), and (110) crystal plane, which is comparative with the XRD pattern of $\mathrm{ZnO}$ powder (JCPDS no. 36-1451). This suggests that a $\mathrm{ZnO}$ phase forms in the complex.

On the other hand, the characteristic diffraction peaks of n-HA located at $25.92^{\circ}, 31.94^{\circ}, 40.12^{\circ}$, $47.01^{\circ}$, and $48.73^{\circ}$ [as shown in Fig. 6(a)] suggest that HA retains its hexagonal structure. However, the wide peaks of n-HA account to its poor crystallization. Further, the (100) peak of $\mathrm{ZnO}$ is overlapped by the (121) peak of n-HA.

The results of XRD data (Table I) indicate a decrease in the $a$ axis and an increase in the $c$ axis of the HA unit cell after compounding. Moreover, the $2 \theta$ degree of $\mathrm{n}-\mathrm{HA} / \mathrm{ZnO}$ decrease in the (004), (002) crystal plain and increase in the (200), (300) plane compared to those of n-HA. According to the Smith-Lehrt formula, the same conclusion can be made, i.e. the trends in the lattice parameters can be largely attributed to the ion exchange. Moreover, the content of $\mathrm{ZnO}$ is up to $7.54 \mathrm{wt} \%$ by AAS analysis, whereas the theoretical value of $\mathrm{ZnO}$ is $10 \mathrm{wt} \%$. This difference implies that part of $\mathrm{Zn}^{2+}$ ion has not formed $\mathrm{Zn}(\mathrm{OH})_{2}$, and enters into n-HA lattice. The diameter of $\mathrm{Zn}^{2+}$ is smaller than that of $\mathrm{Ca}^{2+}$, and so it causes a contraction in the $a$-axis and expansion in $c$-axis dimensions in the complex compared to $\mathrm{n}$ HA. As we know, HA belongs to the hexagonal system with a space group of $\mathrm{P}_{6} 3 / \mathrm{m}$. For B-type, the charge compensation can take place by $-\mathrm{OH}$ and

*Determined from the database JADE (Materials Data Inc.). 
TABLE I

The Lattice Parameter and Crystal Size of n-HA, $\mathrm{ZnO}^{\mathrm{a}}$ and n-HA/ZnO Composites

\begin{tabular}{|c|c|c|c|c|}
\hline Sample & n-HA & $\mathrm{ZnO}^{\mathrm{a}}$ & \multicolumn{2}{|c|}{ n-HA/ZnO Composite } \\
\hline $\begin{array}{l}\text { Lattice parameter }(\AA) \\
d \text {-space }(\AA)\end{array}$ & $\begin{array}{c}a=b=9.4179 \\
c=6.8853 \\
d(002)=3.4476 \\
d(004)=1.7217 \\
d(300)=2.7217 \\
d(200)=4.0703\end{array}$ & $\begin{array}{c}a=b=3.2498 \\
c=5.2066\end{array}$ & $\begin{array}{c}a=b=9.4077 \\
c=6.8855 \\
d(002)=3.4479 \\
d(004)=1.7227 \\
d(300)=2.7186 \\
d(200)=3.8904\end{array}$ & $\begin{array}{c}a=b=3.2496 \\
c=5.2069\end{array}$ \\
\hline & & $\begin{array}{l}d(002)=2.6033 \\
d(101)=2.4759 \\
d(102)=1.9111 \\
d(110)=1.6247\end{array}$ & & $\begin{array}{l}d(002)=2.6064 \\
d(101)=2.4781 \\
d(102)=1.9126 \\
d(110)=1.6258\end{array}$ \\
\hline
\end{tabular}

${ }^{\text {a}}$ From JCPDC database (No.: 89-0511).

Ca vacancies. ${ }^{22,24}$ When $\mathrm{Zn}$ is substituted for Ca of the n-HA, it may alter the balance of the charge defect for the compensation system. Thus the $a, b$ lattice parameter was found to decrease by $0.11 \%$, whereas the $c$ parameter changed little, only increasing by $0.003 \%$ in the new system. Besides, the $\mathrm{Zn}$ of $\mathrm{ZnO}$ coordinates with the $\mathrm{O}$ in $\mathrm{PO}_{4}^{3-}$ of n-HA act as a bridge to $\mathrm{PO}_{4}^{3-}$ groups, which is another reason for the occurrence of the changes in the n-HA unit cell. On the other hand, some differences exist also in the lattice parameters of $\mathrm{ZnO}$ in the complex compared to the standard $\mathrm{ZnO}$, which may also be assigned to ion exchange and the bidentate coordination bonding between the $\mathrm{ZnO}$ and $\mathrm{PO}_{4}^{3-}$ group.

$\mathrm{Zn}(\mathrm{II})$ interaction with HA had indicated different mechanisms. Xu et al. ${ }^{25}$ and Lusvardi et al. ${ }^{26}$ suggested that ion exchange was a possible mechanism for the $\mathrm{Zn}$ bearing HA. Based on the discussion above, it can be speculated that these lattice changes may result from ion-ion, ion-dipole, and dipoledipole interaction, translation, rotation, and vibration. Accordingly, the possible effective geometry can be schematically depicted as Figure 7 .

\section{Antibacterial capability assays}

Table II illustrates the results of the bacteriolytic plate assay. The results show that only the n-HA/ $\mathrm{ZnO}$ complex has an antibacterial effect on E. coli and S. aureus.

Figures 8 and 9 show the inhibition effect of the various materials at different concentrations on the growth of $E$. coli and $S$. aureus. The absorbance at $260 \mathrm{~nm}\left(A_{260}\right)$ characterizes the number of microorganisms in the cultured medium. ${ }^{27}$ Lower absorbance means a higher antibacterial effect of the material. It can be seen that control II is only slightly different from that of the control I material after $24 \mathrm{~h}$, which have $A_{260}$ values of 1.90 and 2.06, respectively. This suggests that the n-HA has no inhibiting effect on E. coli and S. aureus, while the n-HA/ZnO complex shows high antibacterial activities against S. aureus and E. coli at $24 \mathrm{~h}$.

The antibacterial rates of both control I and control II are zero suggesting no antibacterial activity. In contrast, the antibacterial rates of the n-HA/ZnO complex are evident, which is above $87 \%$ against both E. coli and S. aureus (Table III).

\section{Antibacterial mechanism}

As stated above, the n-HA/ $\mathrm{ZnO}$ complex shows a good antibacterial activity, while pure n-HA has no effect on E. coli and S. aureus, which suggests that $\mathrm{ZnO}$ provides the complex with the antibacterial property. This difference may associate with the antibacterial mechanism of $\mathrm{ZnO}$. Generally, there are two kinds of theories to explain the antibacterial mechanism of $\mathrm{ZnO}$. The one holds that metal zinc can react with water and release $\mathrm{Zn}^{2+}, 28$ which subsequently decomposes the bacterium. The other theory is based on light-catabolism ${ }^{29}$ and advocates that $\mathrm{ZnO}$ generates activated oxygen $(\cdot \mathrm{OH})$ under light, especially under UV light. The $\cdot \mathrm{OH}$ combines with sulfhydryl groups of the respiratory enzyme or the nucleic acids in bacteria and stop the breath of bacteria.

$\mathrm{e}^{-}$and $\mathrm{h}^{+}$will appear after UV irradiation, and further form $\cdot \mathrm{OH}$ and $\cdot \mathrm{O}_{2}^{-} \cdot{ }^{11}$ When $\cdot \mathrm{OH}$ comes in contact with the cell, it may destroy the cell wall and membrane, or interact with protein thiol groups, causing the cytoplasm to run off and oxidizing the cell nucleus, which finally induces the death of the bacteria. ${ }^{30} \cdot \mathrm{O}_{2}^{-}$ions are the feasible chemical species at the reduction of oxygen molecule. It is found that the reduced oxygen plays as the antibacterial chemical species. According to the antibacterial theory, it may be explained that the rates of the $\mathrm{n}-\mathrm{HA} / \mathrm{ZnO}$ complex under light are higher than those without light toward bacteria. 


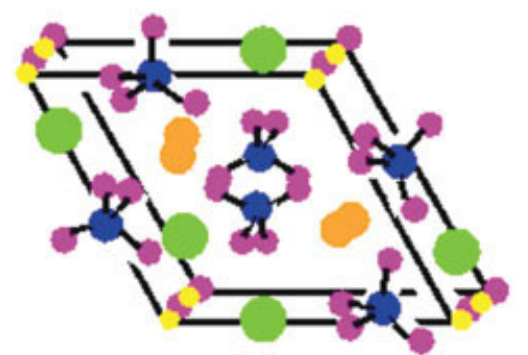

(a)

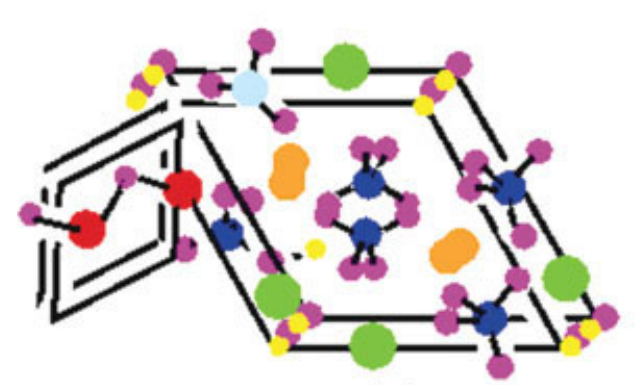

(c)

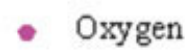

Screw axis Calcium

Vacant calcium

hydrogen

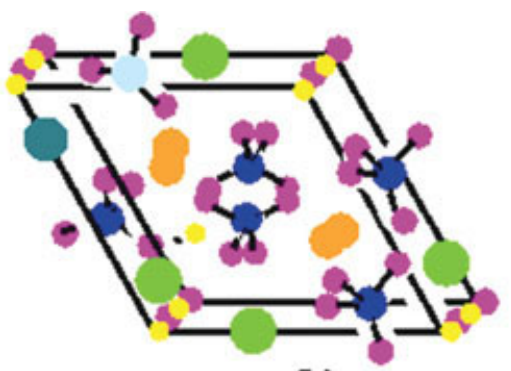

(b)

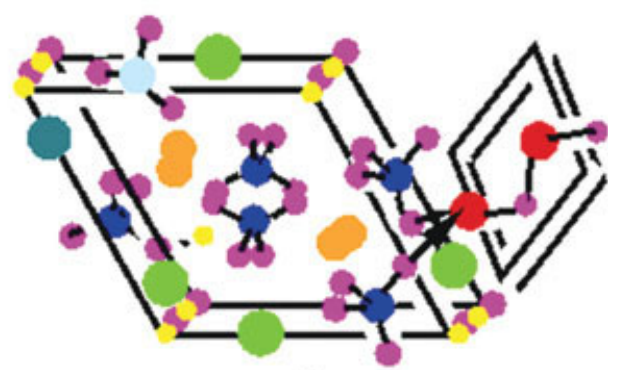

(d)

- Phosphorous

\section{Calumnar Calcium}

Zinc

carbon

Figure 7. Schematic model of structures: (a) n-HA; (b) $\mathrm{CO}_{3}^{2-}, \mathrm{HPO}_{4}^{2-}$ substituted n-HA; (c) ZnO occupying lattice sites of $\mathrm{n}-\mathrm{HA}$; (d) $\mathrm{O}-\mathrm{Zn}-\mathrm{O}$ coordination bonding between $\mathrm{ZnO}$ and $\mathrm{n}-\mathrm{HA}$. [Color figure can be viewed in the online issue, which is available at www.interscience.wiley.com.]

Tables II and III show that the n-HA/ $\mathrm{ZnO}$ complex is more effective for $S$. aureus whether under light or not. Accumulating evidence shows that the complex exerts a high antibacterial activity against gram-positive but not gram-negative bacteria. The outer membrane, covering the cytoplasmic membrane and peptidoglycan layer of gram-negative bacteria, is composed of lipopolysaccharide (LPS), which restricts antibacterial ions passing across the outer membrane of gram-negative bacteria. On the other hand, this complex is able to cause permeabili- zation of both S. aureus and E. coli cytoplasmic membranes. However, the level of permeability of $S$. aureus cytoplasmic membrane is markedly higher than that of E. coli. This may be due to the outer membrane barrier of E. coli, which somewhat prohibits antibacterial ions accessing the cytoplasmic membrane. Consequently, the $\mathrm{n}-\mathrm{HA} / \mathrm{ZnO}$ complex is more effective for S. auerus than E. coli.

Besides, Figure 10 shows the effects of the n-HA/ $\mathrm{ZnO}$ complex on the cleavage of pUC18 extracted from JM no. 109 after different incubation times.

TABLE II

Diameters of Bacterium Repress (in circle/mm)

\begin{tabular}{|c|c|c|c|c|}
\hline & \multicolumn{2}{|c|}{ E. coli } & \multicolumn{2}{|c|}{ S. aureus } \\
\hline & Under Light & No Light & Under Light & No Light \\
\hline n-HA/ZnO composite & $14.50 \pm 0.05$ & $13.00 \pm 0.1$ & $16.00 \pm 0.4$ & $14.75 \pm 0.15$ \\
\hline Control I & 0 & 0 & 0 & 0 \\
\hline Control II & 0 & 0 & 0 & 0 \\
\hline
\end{tabular}

A control I assay was carried out without material, while control II assay was only n-HA powder. 


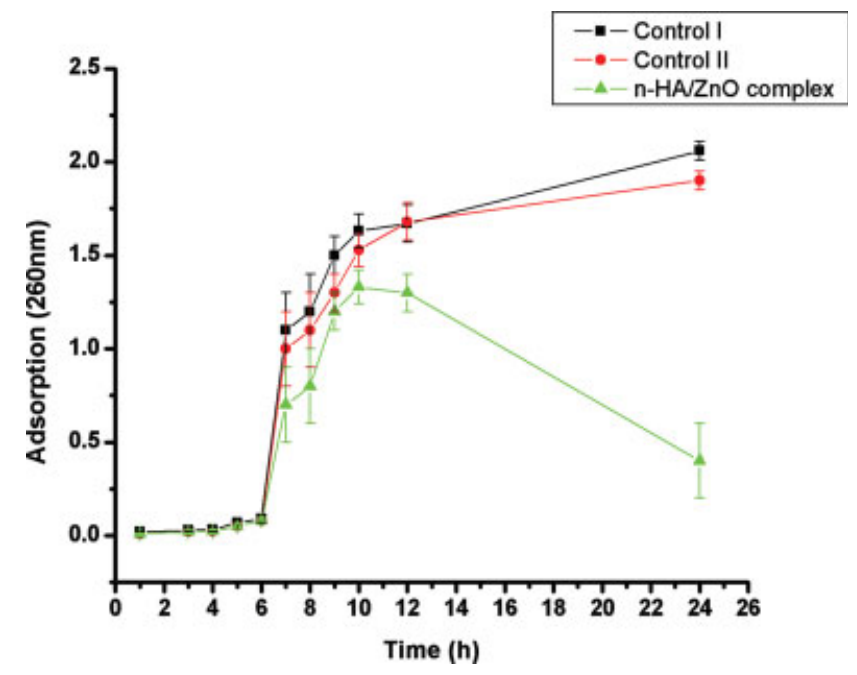

Figure 8. Antibacterial activities of samples against E. coli with the incubation time. A control I assay was carried out when no material was added to the peptone solution. A control II assay was carried out when only n-HA powder was added to the peptone solution. The concentration of the samples was $1 \mathrm{~g} / \mathrm{mL}$. [Color figure can be viewed in the online issue, which is available at www.interscience. wiley.com.]

Form 2 does not appear in control I and control II, which indicates that n-HA cannot accelerate the plasmid DNA cleavage. On the other hand, DNA cleavage would efficiently be accomplished by dissolving $\mathrm{Zn}^{2+}$ of $\mathrm{n}-\mathrm{HA} / \mathrm{ZnO}$ complex. As shown in

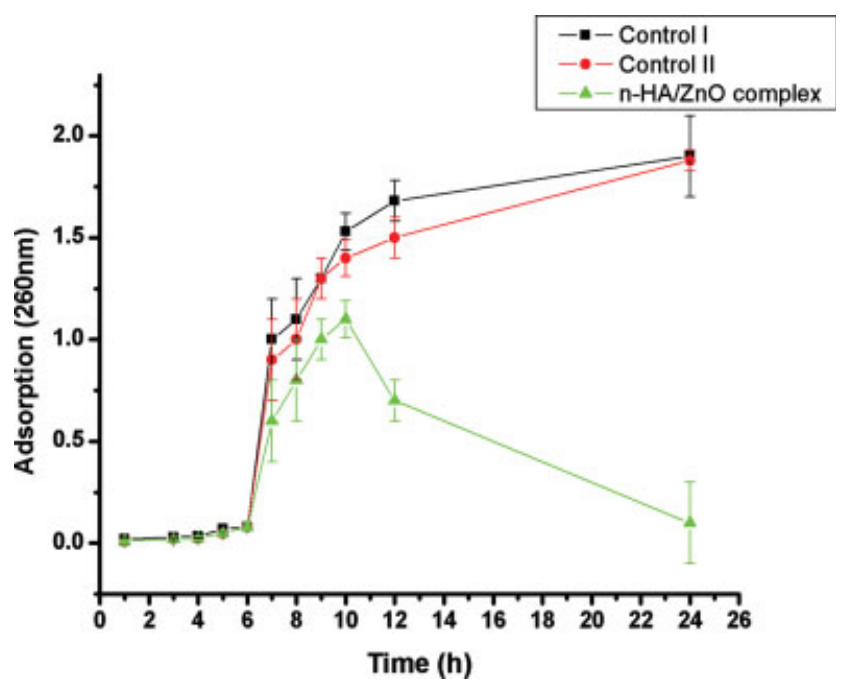

Figure 9. Antibacterial activities of samples against $S$. aureus with the incubation time. A control I assay was carried out when no material was added to the peptone solution. A control II assay was carried out when only n-HA powder was added to the peptone solution. The concentration of the samples was $1 \mathrm{~g} / \mathrm{mL}$. [Color figure can be viewed in the online issue, which is available at www. interscience.wiley.com.]
TABLE III

Results of the Antibacterial Rates of the n-HA/ZnO Composite Against Bacteria

\begin{tabular}{lcc}
\hline & \multicolumn{2}{c}{ Antibacterial Rate (\%) } \\
\cline { 2 - 3 } & Under Light & Without Light \\
\hline E. coli $\left(2.1 \times 10^{6} \mathrm{cfu} / \mathrm{mL}\right)$ & 95.65 & 87.48 \\
S. aureus $\left(1.9 \times 10^{6} \mathrm{cfu} / \mathrm{mL}\right)$ & 99.45 & 91.32 \\
\hline
\end{tabular}

Note: cfu denotes colony forming unit; $2.1 \times 10^{6} \mathrm{cfu} /$ $\mathrm{mL}, 1.9 \times 10^{6} \mathrm{cfu} / \mathrm{mL}$ are the concentration of bacteria used in antibacterial test experiments.

Figure 10, it can be deduced that with a prolong reaction time, form 1 can be efficiently transformed to form 2 at $300 \mathrm{~min}$. As shown in the study, it shows better DNA cleavage ability after combining to filtrate off the n-HA/ZnO complex. In this catalytic cycle, the complex first combined with DNA, $\mathrm{ZnO}$ reacts with $\mathrm{H}_{2} \mathrm{O}$, thus hydroxyl anion coordinated to the metal Zinc may serve as nucleophilic reagent, ${ }^{31}$ as well as the $\mathrm{Zn}^{2+}$ activates the central phosphorus atom. Then, it attacks the phosphorus anion to form a transition state. Meanwhile, the $-\mathrm{OH}$ group of $\mathrm{n}-\mathrm{HA}$ acts also as a nucleophilic reagent and induces the complex to connect with other sides of pUC18. This cooperative effect of n-HA and $\mathrm{ZnO}$ catalyzes the hydrolysis of the 3,5-phosphate diester bond in the DNA sequence. Finally, it breaks up to complete the DNA cleavage (shown in Figure 11 ), inducing the changes of DNA and destroying the bacteria.

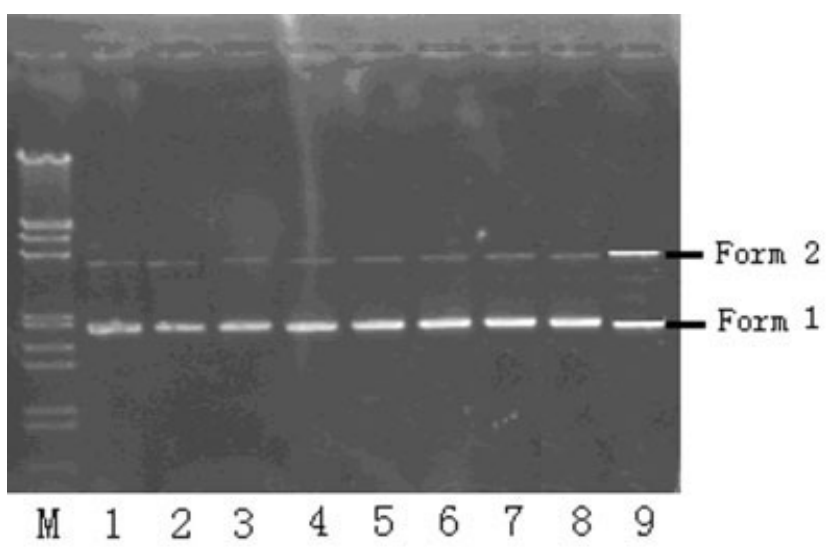

Figure 10. Agarose gel electrophoresis cleavage reaction of E. coli's DNA by the dissolving solution of materials with different time (ethidium bromide staining). Lane 1: Control I, A control I assay was carried out without material; Lane 2: Control II, A control II assay was preformed when only n-HA contacted with pUC18 for 300 min; Lanes 3-9: n-HA/ZnO complex was contacted with pUC18 at 1, $5,10,15,30,60$, and $300 \mathrm{~min}$. 


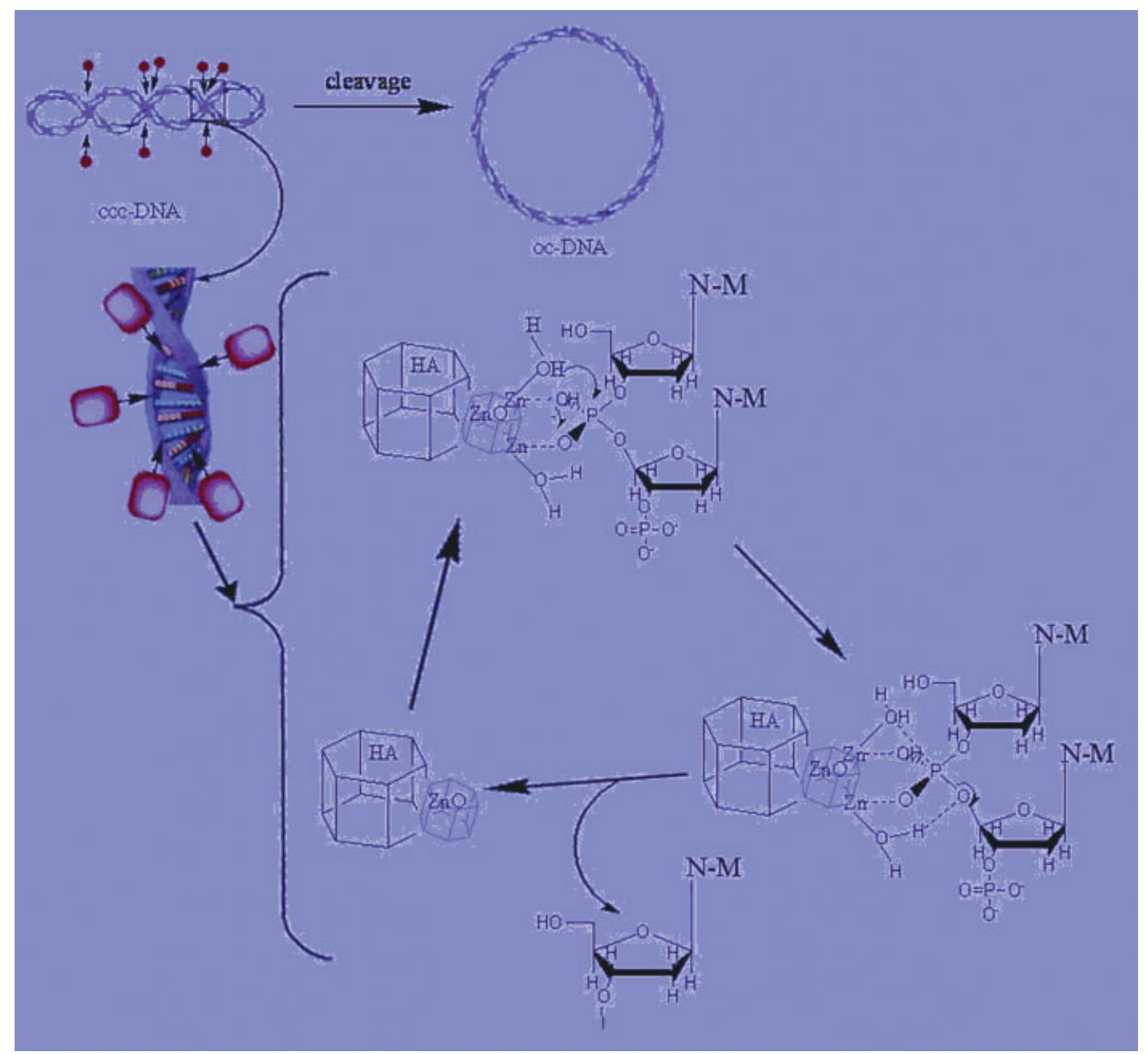

Figure 11. Proposed mechanism of DNA cleavage catalyzed by $\mathrm{n}-\mathrm{HA} / \mathrm{ZnO}$ complex. [Color figure can be viewed in the online issue, which is available at www.interscience.wiley.com.]

\section{CONCLUSION}

n-HA/ZnO complex possesses a nanometer size, and the size, composition as well as structure of nHA change little during complexation. The lattice parameters, a and $\mathrm{c}$, of both n-HA and $\mathrm{ZnO}$ change after compounding. $\mathrm{Zn}^{2+}$ ions of $\mathrm{ZnO}$ can enter the n-HA crystal lattice. The n-HA/ $\mathrm{ZnO}$ complex has a good antibacterial activity, which is $98.65 \%$ and $99.45 \%$ against $E$. coli and $S$. aureus under light, respectively, and the antibacterial activity for $S$. aureus is stronger than that for $E$. coli. The occurrence of antibacterial capability is supposed to be due to the generation of active oxide from the surface of complex and $\mathrm{Zn}^{2+}$ or $\mathrm{OH}^{-}$, which can cleave the 3,5phosphate diester bond, inducing the decomposition of bacteria.

The approach as used in the current study produced a complex with good antibacterial activity properties without sacrificing biocompatibility. The resulting HA-based system holds wide potential for application in clinic as an antibacterial biomaterial, as well as for dental filing and repair.

The authors thank Mr. Chen Shitu for XRD data and Ms. Zhu Xiaohong for IR data.

\section{References}

1. Cordero J, Munuera L. The influence of the chemical composition and surface of the implant on infection. Injury 1996; 27(Suppl. 3):SC34-37.

2. Bauer T, Schils J. The pathology of total joint arthroplasty. II. Mechanisms of implant failure. Skeletal Radiol 1999;28:483497.

3. Garvin KL, Hanssen AD. Current concepts review: Infection after total hip arthroplasty: Past, present, and future. J Bone Joint Surg Am 1995;77:1576-1588.

4. Joosten U, Joistm A. Evaluation of an in situ setting injectable calcium phosphate as a new carrier material for gentamicin in the treatment of chronic osteomyelitis: Studies in vitro and in vivo. Biomaterials 2004;25:4287-4295. 
5. Wilczynski M. Anti-microbial porcelain enamels. Ceram Eng Sci Process 2000;21:81-83.

6. Sawai J. Quantitative evaluation of antibacterial activities of metallic oxide powders $(\mathrm{ZnO}, \mathrm{MgO}$, and $\mathrm{CaO})$ by conductimetric assay. J Antibact Antifungal Agents 2003;54:177-182.

7. Grogan J, McKnight CJ, Troxler RF, Oppenheim FG. Zinc and copper bind to unique site of histatin 5. FEBS Lett 2001; 491:76-80.

8. Xie D, Chung ID, Wang GG, Feng DS, Mays J. Synthesis, formulation and evaluation of novel zinc-calcium phosphatebased adhesive resin composite cement. Eur Polym J 2004; 40:1723-1731.

9. Pal B, Sharon M. Enhanced photocatalytic activity of highly porous $\mathrm{ZnO}$ thin films prepared by sol-gel process. Mater Chem Phys 2002;76:82-87.

10. Chen $\mathrm{CZ}$, Zhou ZW, Hu SC. Preparation and investigation of nano-ZnO/HDPE composite. Industry Plastic 2003;10:18-19.

11. Song $Z \mathrm{ZH}$, Sang $\mathrm{Y}$, Zhang XP. Inhibition effect of nanometer ZnO on bacteria. J Qing Dao Technol Univ 2004;3:232-234.

12. Li YB, de Wijn J, Klein CPAT. Preparation and characterization of nanograde osteoapatite-like rod crystals. J Mater Sci Mater Med 1994;5:252-255.

13. Wang XJ, Li YB, Wei J, de Grood K. Development of biomimetic nano-hydroxyapatite/poly(hexamethylene adipamide) composites. Biomaterials 2002;23:4787-4791.

14. Hench LL, Wilson J. An Introduction to Bioceramics. Singapore: World Scientific Press; 1993. p 139-143.

15. Hu ZQ. Inorganic Material Science. Bei Jing: Chemistry and Technology Press; 1998. p 40-41H.

16. Li YB, de Groot K. Morphology and composition of nanograde calcium phosphate needle-like crystals formed by simple hydrothermal treatment. J Mater Sci Mater Med 1994; 5:326-331

17. Han WY. Pathogenic Bacteria Testing Technology. Jilin: Science and Technology Press; 1992. p 79-80.

18. Sambrook J, Fritsch EF, Maniatis T. Molecular Cloning: A Laboratory Manual, 2nd ed. Cold Spring Harbor, NY: Cold Spring Harbor Laboratory Press; 1989. p 21-33.
19. Hoogewijs R, Fiermans L, Vennik J. On the problem of relaxation in photo- and Auger-electron emission. J Microsc Spectrosc Electron 1976;1:109-110.

20. Gaarenstroom SW, Winograd N. Initial and final state effects in the ESCA spectra of cadmium and silver oxides. J Chem Phys 1977;67:3500-3509.

21. Kumar R, Prakash KH, Cheang P. Temperature driven morphological changes of chemically precipitated hydroxyapatite nanoparticles. Langmuir 2004;20:5196-5200

22. Astala R, Strtt MJ. First principles investigation of mineral component of bone: $\mathrm{CO}_{3}^{2-}$ substitutions in hydroxyapatite. Chem Mater 2005;17:4125-4133.

23. Lee JY, Evert J. Sorption mechanisms of zinc on hydroxyapatite: Systematic uptake studies and EXAFS spectroscopy analysis. Environ Sci Technol 2005;39:4042-4048.

24. Driessens FCM, Verbeeck RMS, Kiekens PZ. Mechanism of substitution in carbonated apatites. Zeitschrift fuer Anorganische and Allgemeine Chemie 1983;504:195-200.

25. Xu Y, Schwartz FW, Traina SJ. Sorption of $\mathrm{Zn}^{2+}$ and $\mathrm{Cd}^{2+}$ on hydroxyapatite surface. Environ Sci Technol 1994;28:14721480 .

26. Lusvardi G, Menabue L, Saladini M. Reactivity of biological and synthetic hydroxyapatite towards $\mathrm{Zn}$ (II) ion, solid-liquid investigations. J Mater Sci Mater Med 2002;13:91-98.

27. Jeon YJ, Kim SK. Production of chitooligosaccharides using an ultrafiltration membrane reactor and their antibacterial activity. Carbohydr Polym 2000;41:133-141.

28. Li YF, Tu MJ. Study on the antibacterial properties of nanometer inorganic antibacterial materials. New Chem Mater 2002;30:44-46.

29. Zhao XD, Yao JB, Yi D. Study on the antibacterial properties of $\mathrm{ZnO}$. Dyeing Tech 2005;1:13-15.

30. Li CQ, Luo XL, Fu MG. The research on antibacterial materials. New Mater Chem Eng 2005;5:32-33.

31. Xiang QX, Zhang J, Liu PY. Dinuclear macrocyclic polyamine zinc(II) composites: Syntheses, characterization and their interaction with plasmid DNA. J Inorg Biochem 2005;99:16611669. 